\title{
The Effectiveness of Chinese Monetary Policy during the 2008 Financial Crisis
}

\author{
Yiming $\mathrm{Li}^{1, \mathrm{a}}$ \\ ${ }^{1}$ Department of Economics, University of Washington, Seattle, WA, 98105, U.S.
}

\begin{abstract}
The objective of this paper is to explain the factors that led to the effectiveness of Chinese monetary policies during the financial crisis. As the crisis hit China, China's economy faced two external shocks in the investment and export sector. The reliance on the international market, together with its constrained monetary policy and institutional problems, make it worthwhile to consider why China was the first country that recovered from the financial crisis. Through the analysis, the paper identifies three sources of the efficiency. The first concerns with the previous economic health. The second involves the wellcoordinated fiscal and monetary policies and the last derives from China's institutional characteristics. Moreover, it is argued that some policies made during the financial crisis may carry risks and other negative implications in the long run. The paper focuses on two of them, namely the implications on the real estate market and economic restructuring.
\end{abstract}

\section{INTRODUCTION}

The position of China's economy around 2008 is far from ideal in the general sense. China's economy is heavily dependent on global trade and investment flows. The main question this paper wants to address is this: how is it possible for the monetary policies to be so effective against the serious odds? Indeed, China is back on track having 11.9 percent growth of GDP by the first quarter of 2010 as a result of the expansionary policies. The purpose of the paper is to present a more wholistic picture of the situation, that is, its purpose is to understand the situation better in retrospection.

\section{THE ECONOMIC DEVELOPMEN AND SITUATION OF CHINA}

The position of China's economy around 2008 is far from ideal in the general sense. China's economy is heavily dependent on global trade and investment flows. In the four years leading to the financial crisis of 2008, the ratio of export to GDP ranged 31 to 36 percent (figure 1)

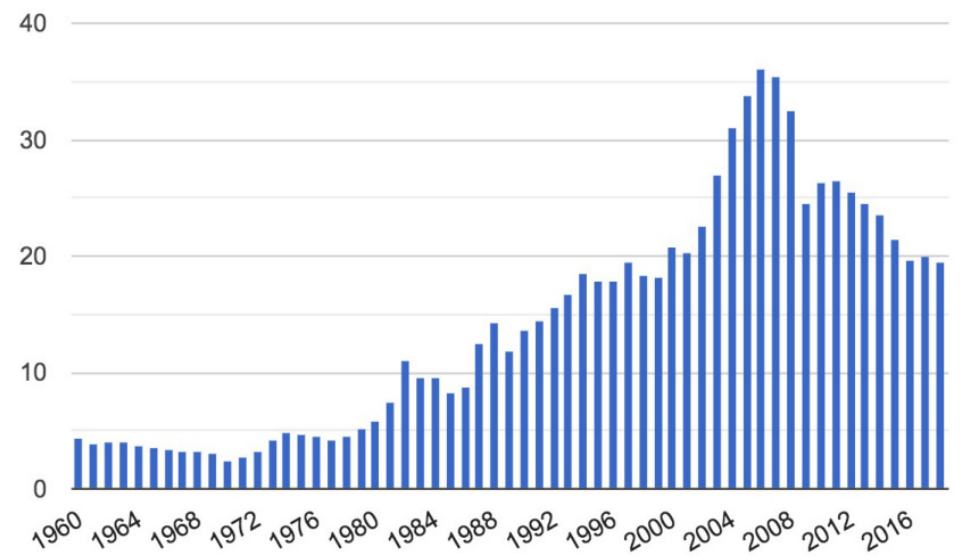

Figure 1. China - Exports, percent of GDP.

In 2007, China replaced the U.S. as the second largest merchandise exporter with its net export contributed to one-third of its GDP growth. On the other hand, it is suspected that China owned a large amount of troubled
U.S. mortgage securities. If the speculation is correct, the main risk would come from the public sectors owning corporate securities and U.S. equities that had been invested in real estate. During the crisis, China faced two 
serious external shocks. First, the falling international demand dealt a serious blow to Chinese export sector (figure 2).

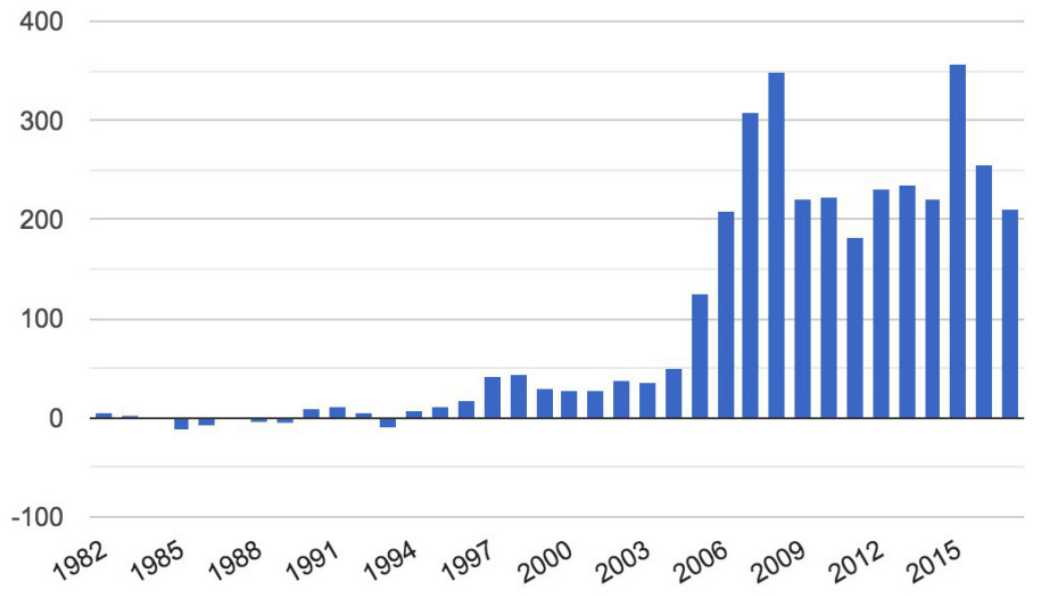

Figure 2. China - Balance of Trade.

Second, the fading inflation pressure and the collapse of the commodity markets caused the firms to de-stock and heavily suppressed the investment demand. As a result, Chinese GDP growth decreased from $13 \%$ to $6.1 \%$ from 2007 to 2009. Observing this, the Chinese government quickly intervened and the expansionary monetary proved to be extremely effective and led to a rebound in the economic growth in the second quarter of 2009. However, this is by no means expected. First, the Chinese monetary policy is constrained by the managed float rate regime. Rmb was pegged to the dollar from the 1990s to until 2005 after which according to the People's Bank of China (PBC), Renminbi was managed against an undisclosed basket of currencies. This exchange rate regime has restricted $\mathrm{PBC}$ 's ability to use interest rate as stimulate the economy. A further constraint is institutional: banks' deposit and lending rates were directly controlled by the government. The Chinese government set two baselines for lending and deposit rates so that the minimum spread cannot be reduced by competitive behavior from the banks (figure 3). As noted [1], in practice, actual lending and deposit rates cluster around the baseline rates, implying the non-competitive behavior compromised the effects of interest rate liberalization. Coupled with this is the sticky, low-cost retail deposits in the major state-owned banks. These deposits tend to be less interest-sensitive and posed a change to effective monetary transmission.

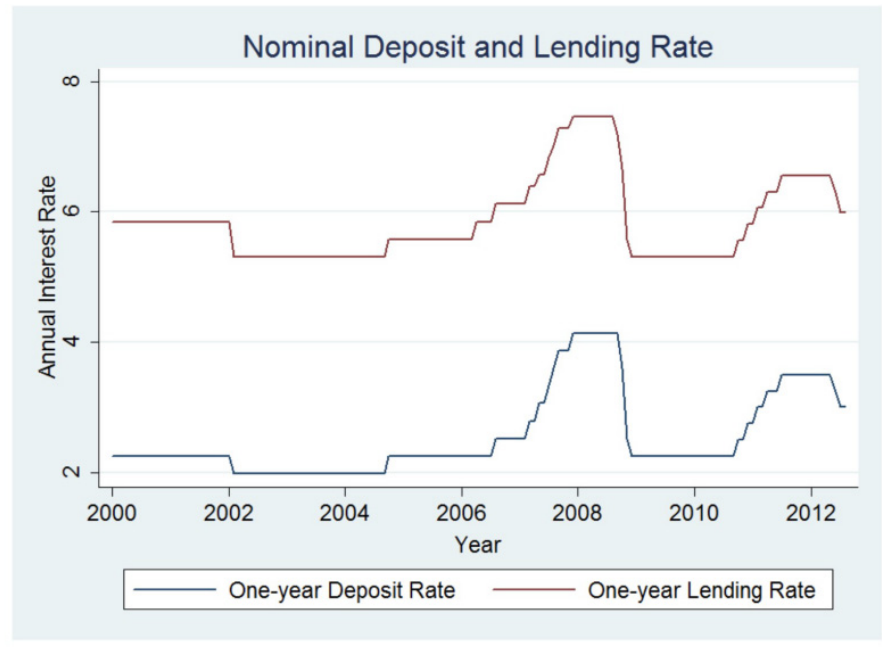

Source: People's Bank of China.

Figure 3. China - Benchmark Deposit and Lending Rates.

Moreover, prior to 2008 , Chinese monetary policy framework focused on quantity control, a legacy of planned economy. Under this framework, when market demand for reserve rises, the monetary authority faces the dilemma of liquidity crisis and interest rate fluctuation, which are both detrimental to financial stability. In 20082009, Chinese monetary policy was just starting to transition toward an "interest rate maintenance mode" and 
its position could be vulnerable due to lack of experience and institutional constraints.

\section{PREVIOUS ECONOMIC HEALTH}

It is worth examining to what extent the common believes on China's economy hold in the context of the global financial crisis. First, compared to the major Western banking systems (Federal Reserve System, European System of Central Banks and etc.), China's banking system was relatively safe and sound: there was no liquidity shortage, no credit crunch, and the monetary multiplier remained robust during the crisis. Second, over the decades leading to 2008, China's budget deficit was very low. The deficit in 2007-2008 was no more than 0.4 percent of total GDP. For comparison, the ratio for U.S. in 2007-2008 was around 1 to 3 percent. This directly enabled the active fiscal intervention marked by the 4 trillion (Rmb) stimulus package for 2009 and 2010. Besides, with the short term interest rate around 4.5 in the period leading to the crisis, the monetary authority had a lot of room to implement its expansionary policy. Moreover, as shown using a factor-augmented VAR [2], the channels of transmission for Chinese monetary policy have become closer to those of Western market economies from 2000 to mid-2013.

Besides, prior to the financial crisis, due to $\mathrm{PBoC}$ 's intervention in the exchange market, China had accumulated a large base of liquidity, which once made the inter-bank interest rates lower than interest on deposits in commercial banks. This enabled the dramatic increase in bank credits and M2 supply around the fourth quarter of 2008 when the PBoC stopped contractionary open market operations.

\section{THE COUPLING OF MONETARY AND FISCAL POLICIES}

Since 2009, the People's Bank of China (PBoC) has adopted a mildly expansionary monetary policy to support the expansionary fiscal policy. Firstly, PBoC lowered interest rate and adjusted banks' reserve requirements rate. This effectively brought down long-term interest rate and thus triggered more investment spending. Secondly, the Chinese government implemented a series of measures that facilitate the credit guarantee service, making it easier for people to borrow. This increase in consumer credit availability increased private consumption. On the other hand, the State Council, which directly controls the PBoC, decided to loosen control on mortgage loan. This was necessary for the real estate market because there was a lot of demand spilling over from 2007 and the onset of global financial crisis stopped a lot of projects that had yet been completed. To save business from potentially devastating losses, the State Council thus decided to back up the housing demand. Thirdly, the PBoC kept Rmb exchange rates stable to mitigate the export decline. This is essentially an extension of the previous managed float exchange rate regime which has led to some political tension. Under the float exchange rate regime, the $\mathrm{PBoC}$ has accumulated excessive foreign reserves as some scholars argued [3]. On the other hand, the better known response is perhaps the 4 trillion yuan stimulus package. The source of funding came from three levels: central government spending, local governments and bank lending. Its rough decomposition is given in figure 4. A fiscal expansion of this magnitude was directly enabled by the previous low budget deficit as mentioned in the last section. Even at the end of 2009, China's ratio of debt balance to GDP was only about 20 percent. The most important components of this stimulus package are transportation network, Sichuan post-earthquake reconstruction and rural infrastructure. These spending plans worked in intimate conjunction with the loose monetary policy. Unlike developed countries like the U.S. and Switzerland, in China there is a serious gap in living standards between rural and urban areas [4]. By bettering the infrastructure and transportation network in these areas, firms may find it profitable to invest in the less developed places which may in turn stimulate consumption. This is coupled with the loose bank credits and created a "multiplier process". Arguments have been made against the big infrastructure push [5] in that its future returns can be worrying due to the scale and hasty implementation of the investment.

\begin{tabular}{lc}
\hline Construction of houses for low income urban households & 280 \\
\hline Increased spending on rural infrastructure and boosting rural incomes & 370 \\
\hline Expenditures in transportation network construction & 1800 \\
\hline Increased investment on medical service, culture and education & 40 \\
\hline Increased spending on ecology protection & 350 \\
\hline Technical innovation and economic restructuring & 160 \\
\hline Sichuan post-earthquake reconstruction & 1000 \\
\hline total & 4000 \\
\hline
\end{tabular}

Source: China National Development and Reform Commission

Figure 4. Spending Structure of 4 trillion Yuan Stimulus Package (Unit: billion Yuan). 
Another important aspect of the stimulus plan is the large amount of tax rebates for export. According to the State Administration of Taxation, export tax rebates for some textile and garment items were increased to 13 percent starting from August 1, 2008. At the time when this stimulus plan was adopted, the amount of rebates was planned to be 670 billion yuan, which was about 15 percent of the total government expenditure for the year. Existing studies have shown that ETR (export tax rebates) has a positive impact on China's export volume [6], but the degree varies substantially across Chinese industries [7]. With its large base of foreign reserve, the $\mathrm{PBoC}$ was quite successful in keeping exchange rate stable. As a result, the spot exchange rate for USD to CNY fluctuated between 6.89 to 6.82 from December 2008 to July 2010, after which Rmb gradually appreciated. This behavior is shown to be conductive to fiscal expansion [8].

Some scholars argued that the combination of policies are overly aggressive and can be highly problematic. First, the long history of China relying on export has led to serious overused of domestic resources, which may cause environmental problems in the near future. Second, this rebate scheme has become a heavy fiscal burden on the central government [9]. Last, its negative impact on the rationalization of the economic structure is equally obvious since China's economic growth is unlikely to be sustainable with export as its main driving force. Some of the long-term implications are discussed in a later section.

\section{INSTITUTIONAL CAUSE}

Behind all of the previously mentioned policies to counter the economic downturn is a highly centralized government regime. It is a well-known fact that the PBoC's legal status is low compared to its western counterparts in the sense that it is subject to the decisions of the State Council. The State Council enjoys the final decision-making power on annual money supply, interest rates, exchange rates and other major monetary policy matters. The State Council, however, can have political incentives that are heavily influenced by the party leader. Each meetings of the State Council is presided over by a Standing Committee that includes the premier, one executive vice premier, three vice premiers, and five other state councilors. The vicepremiers and state councilors are all appointed by the president who can exert influence on the decision-making process. On the other hand, in China, the Ministry of Finance is in charge of fiscal policy. The ministry also records and publishes all the annual macroeconomic data on China's economy. However, the Ministry of Finance's remit is much more limited than its counterpart in, for instance, the U.S. because general issues concerning macroeconomic management are handled by the National Development and Reform Commission (NDRC). In this sense, though the power of the Ministry, NDRC and PBC are equal in legal status, each has relatively constrained power. What enabled them to form a consistent goal and coordinate their policies is the fact that all of their political authorities are part of the State Council, which in turn is dominated by the Standing Committee. This highly stratified structure, while taking away some of the independence of each administrative branches, also enables quick and efficient response in times of financial instability. Though this coordination mechanism between the Chinese "Treasury" and $\mathrm{PBoC}$ is shown to be problematic [10] under an interest-targeting framework, there is also evidence that channels of transmission for Chinese monetary policy have become closer to those of Western market economies [2].

\section{LONG TERM IMPLICATION}

This section focuses on two long term implications of the expansionary policies on the real estate market and economic restructuring.

Prior to 1998 , the real estate market only played a secondary role in Chinese economy because real estate was perceived more as something of practical value and part of employment benefit. After the commercialization of real estate of 2008, it took a while for the market to respond with a huge investment demand. On the other hand, prior to 2005, China had been keeping RMB fixed to the U.S. dollar, and as a result, had accumulated a large liquidity base, which also contributed to the boom in the real estate market. Between 2002 and 2006, real estate price skyrocketed. The loosening of control on mortgage loan during the financial crisis triggered a lot of political controversy. It is showed [11] that much of the increase in housing prices is occurring in land values. In China, land is publicly owned and by artificially elevating the demand for real estate, some government officials can benefit from higher price of the same land parcel. This in turn implies that measures to curb the overheating real estate market are likely to ineffective, which in turn gives speculators incentive to pour their capital into the market. The widely held belief that there is a serious housing bubble in China has been tested against several criteria. Firstly, the housing prices-to-income ratio normally ranged from 3 to 6 in the developing countries and lower in developed countries. For China, this ratio is astoundingly high, especially for cities like Beijing and Shanghai. In 2011 this ratio in Beijing was $27: 1$. Secondly, the prices-to-rent ratio is often used as a sign to indicate the extent to which housing prices deviate from the fundamental value. Commonly $300: 1$ is taken as sign for real estate bubble. This ratio in Beijing also has climbed up to 500:1 in 2011. Other statistics such as vacancy rate may also serve as indicators and all of them suggest the presence of a real estate bubble. The cause is manifold but the most significant factors include speculation, bank credit and government policies. The speculation is fueled by the belief that the government will do their best to stop real estate price from falling and PBoC's reaction to the financial crisis reaffirmed this. Prior to the crisis, the banks' competitive behavior in the housing market is badly controlled: the banks routinely violated regulations on credit rating because of the high return and released a large number of loans to developers. To save the commercial banks from bankruptcy, the PBoC further lowered mortgage rates during the crisis. Besides, speculators were confident as China's local governments heavily rely on land sale revenues and use future land sale revenues as collateral to raise debt financing through 
Local Government Financing Platform [12]. Due to this the price is unlikely to go down in the short run. In a sentence, the monetary policy is facing a dilemma because controlling bank credits implies new housing projects may suffer from shortage of expected funding and become halted. As a consequence, previous bank loans will become non-performing. Otherwise, the government is destined to face serious asset bubble in the future.

On the other hand, doubts have been cast on the fiscal stimulus package in that it might not perform as expected. This plan was deliberately designed to focus on those sectors in which projects would generate significant and long-term benefits as well as being capable of rapid implementation. Since the economic reform in the 1980s, China has relied on the investment and industrial sectors for its economic growth. With healthcare and education taking only percent of the total spending, the stimulus program is likely to enlarge the already wide gap between the manufacturing and service sector, delaying the process of structural reform. However, the consequence is less serious than expected. The share of secondary industries (construction and industry) as part of GDP gradually declined since 2009 and the tertiary industries experienced a steady expansion, leading to a surprising reversal of status in 2013 (figure 5,6,7).

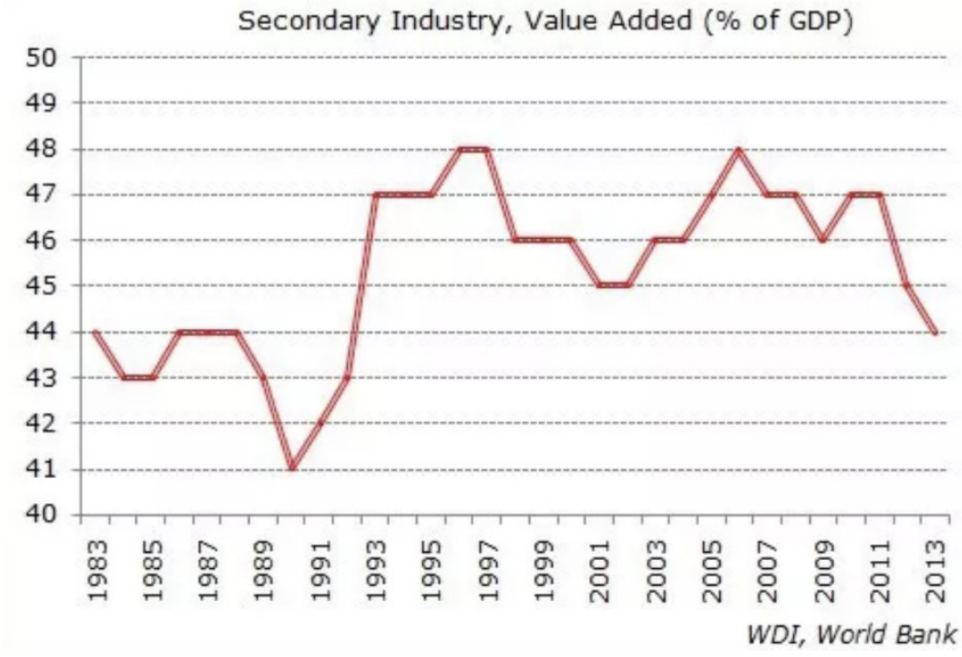

Figure 5. Value Added in Secondary Industry as a Percent of GDP (1983-2013)

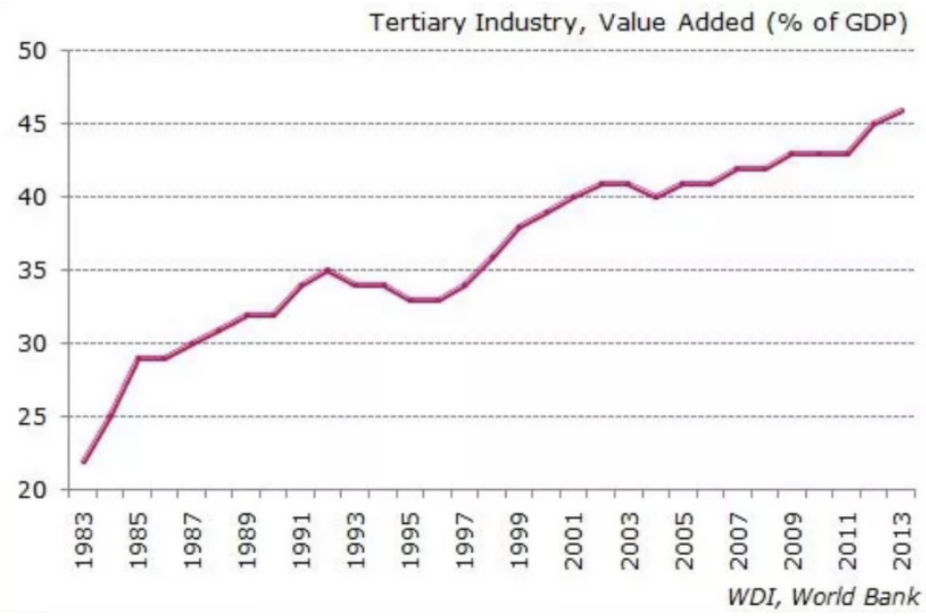

Figure 6. Value Added in Tertiary Industry as a Percent of GDP (1983-2013) 


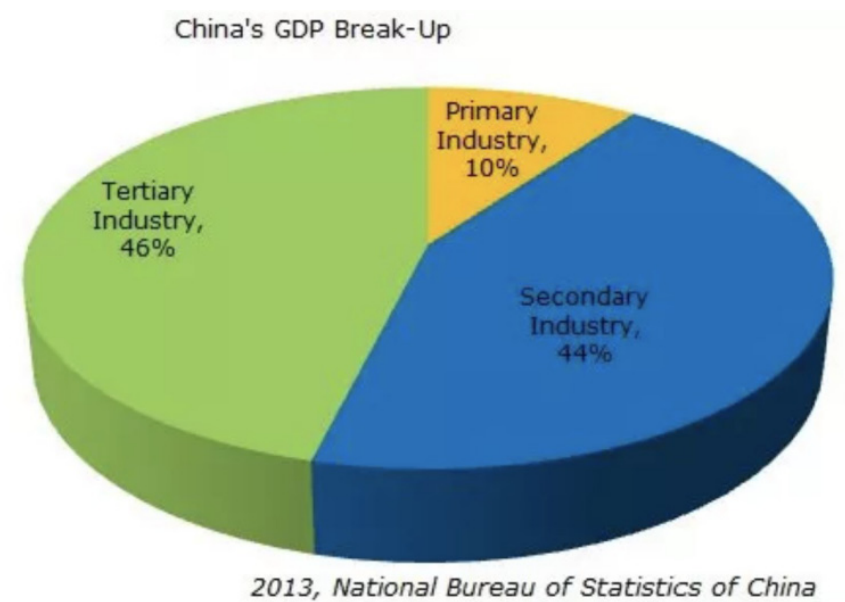

Figure 7. The Composition of China's GDP in 2013

Part of the reason why this change took place is that the 2008 financial crisis exposed the problems of overcapacity. Specifically, the financial crisis dwindled the foreign markets' demand of goods produced in China and unproductive investment yield debt build-up. The decision to shift from an investment-driven economy to a consumption driven one led the government put more focus on the service sector and several laws have been passed to liberalize the restrictions to enter into health care, sanitation, education, finance and other parts of the service sector since 2009. Although the over-reliance on foreign market is still a problem today, the Chinese government has found new ways to tackle the issue (such as the Belt and Road Initiative).

\section{CONCLUSION}

The paper shows that the contributors to the quick rebound of Chinese economic growth during the 2008 global financial crisis are numerous and complex. The previous economic stability and government revenue ensured the possibility of the aggressive monetary and fiscal policies. Due to the special institutional structure in China, the PBoC and the Chinese Ministry of Finance were quick in their reaction to the onset of the crisis and coordinated their policies so that they were mutually reinforcing. Although the policies proved to be effective in bringing Chinese economy from the quagmire, they may not be ideal in the long run. The massive fiscal stimulus plan in a way exacerbated China's reliance on foreign market and led to, as some argue, undue budget deficit since its hasty implementation has led to perfunctory projects that were unlikely to generate output in the long run. Besides, the loose control on mortgage loans and bank credits confirmed the real estate market's status as a source of revenue for the local governments. This implies the price is unlikely to go down in the aftermath of the financial crisis due to the large amount of government borrowing and has caused a lot of political, as well as economical concerns.

Also, although market liberalization has made a lot of progress in China, traditional tools may still be insufficient in a highly regularized economy. Since both the fiscal and monetary decision in China are highly politically driven, a detailed study in the politics may be indispensable to understand the true driving forces behind. However, due to regime difference, the findings and implications thereof might not be readily transferable to another country for future economical guidance.

\section{ACKNOWLEDGMENT}

First and foremost, I would like to show my deepest gratitude to my teachers and professors in my university, who have provided me with valuable guidance in every stage of the writing of this thesis. Further, I would like to thank all my friends and roommates for their encouragement and support. Without all their enlightening instruction and impressive kindness, I could not have completed my thesis.

\section{REFERENCES}

1. P. Eswar, and B. Zhang. Monetary Policy in China. The Oxford Companion to the Economics of China, 2014, pp: 194-99. Oxford University Press. https://doi.org/10.1093/acprof:oso/9780199678204.0 03.0030 .

2. J. Fernald, M. Spiegel, and E. Swanson. Monetary Policy Effectiveness in China: Evidence from a FAVAR

Model. Cambridge, MA. 2014. https://doi.org/10.3386/w20518.

3. P. Eswar, Y. Lei. The renminbi's role in the global monetary system, IZA Discussion Papers, No. 6335, 2012. Institute for the Study of Labor (IZA), Bonn, http://nbn-resolving.de/urn:nbn:de:101:1201205026008

4. C.A. Carter. The Urban-Rural Income Gap in China: Implications for Global Food Markets. American Journal of Agricultural Economics. 1997, 79 (5):1410. https://doi.org/10.2307/1244354.

5. Y. Yu. The Impact of the Global Financial Crisis on the Chinese Economy and China's Policy Responses. 2010. 
6. C.C. Chao, S.H. Yu, and W. Yu. "China's Import Duty Drawback and VAT Rebate Policies: A General Equilibrium Analysis." China Economic Review. 2006, $\quad 17 \quad$ (4): $432-48$. https://doi.org/10.1016/j.chieco.2006.02.005.

7. J. G. Xie, and L. L. Chen. Export rebate policy and export of Chinese manufacturers (in Chinese). The Journal of World Economy. 2008, 5: 3-12.

8. M. Ronald, B. Lee, and Y. D. Wang. The Global Credit Crisis and China's Exchange Rate. Singapore Economic Review. 2010, 55 (2): 253-72. https://doi.org/10.1142/S0217590810003705.

9. Z. Cui. China's Export Tax Rebate Policy. China: An International Journal. 2003, 1 (2): 339-49. https://doi.org/10.1353/chn.2005.0035.

10. Z. He, and G. Jia. An Institutional Analysis of China's Reform of Their Monetary Policy Framework. SSRN Electronic Journal. $2019 . \quad$ May. https://doi.org/10.2139/ssrn.3368531.

11. Y. Deng, J. E. Gyourko, and J. Wu. Evaluating Conditions in Major Chinese Housing Markets. SSRN Electronic Journal. 2010. https://doi.org/10.2139/ssrn.1717036.

12. C. Liu. and W. Xiong. China's Real Estate Market. Cambridge, MA $2018 . \quad$.https: //doi.org/10.3386/w25297. 